\title{
A New Approach to the Allocation of Aid Among Developing Countries: Is the USA Different from the Rest?
}

\author{
JANE HARRIGAN \\ University of London, $U K$ \\ and \\ CHENGANG WANG * \\ University of Bradford, $U K$
}

\begin{abstract}
Summary. - This paper attempts to explain the factors that determine the geographical allocation of foreign aid. Its novelty is that it develops a rigorous theoretical model and conducts the corresponding empirical investigations based on a large panel dataset. We run regressions for different major donors (United States, Canada, France, Italy, Japan, United Kingdom, and multilateral organizations). with the explicit objective of establishing whether the United States, in light of its geopolitical hegemony, behaves differently from others. We find that all the donors respond to recipient need in their allocation of aid, but that the United States puts less emphasis on this than the other donors with the exception of Japan. We also find that the United States puts more emphasis on donor-recipient linkages than do the other donors suggesting that the United States attaches greater importance to issues of donor interest, for example, geopolitical, commercial, and other links with specific recipients.

(C) 2011 Elsevier Ltd. All rights reserved.
\end{abstract}

Key words — aid allocation, panel data, USA donor

\section{INTRODUCTION}

"Does aid work?" This question has dominated development literature for the past half a century and yet still the answer seems unclear. There are numerous examples of countries that seem to have used aid to good effect in terms of helping generate economic growth: Taiwan in the 1950s, Botswana and the Republic of Korea in the 1960s, Bolivia and Ghana in the 1980s, and Uganda and Vietnam in the 1990s. Crosscountry studies have provided formal empirical evidence on the positive effect of aid on growth (Burnside \& Dollar, 2000; Dalgaard, Hansen, \& Tarp, 2004; Hansen \& Tarp, 2001; Minoiu \& Reddy, 2010). In addition, according to Collier and Dollar (2002), Official Development Assistance (ODA) alone brings 10 million people out of poverty each year. On the other hand, there is formal and anecdotal evidence that suggests that, in many cases, and in many countries, aid does not work (Bobba \& Powell, 2007; Boone, 1994). Along with the successful stories mentioned above, there are many countries that have received a large amount of foreign aid but performed poorly in terms of economic growth, for instance, Zambia, Zaire, Niger, Jamaica, Nepal, among others (Mosley, Hudson, \& Horrell, 1987) ${ }^{1}$ while countries, such as China, Algeria, and Costa Rica received little aid but have, so far, performed well according to a number of different development indicators.

The often disappointing impact of foreign aid has been attributed to a number of different factors in the literature, including corruption, inefficiencies and bureaucratic failures in the recipient countries (Alesina \& Dollar, 2002), inappropriate conditionality and aid tying ${ }^{2}$ adopted by the donor countries (OECD, 1994), the support for foreign aid among voters in donor countries (Chong \& Gradstein, 2008), and lack of coordination between donors and between donors and recipients (Arne, 2006; Berthélemy, 2006b). Apart from these factors, disappointing aid impact might also be due to the inappropriate manner in which donors allocate their aid. There is one constant in the history of aid - the development objectives of foreign aid are often distorted by donors' commercial, strategic, and political motives, ${ }^{3}$ regardless of donor agencies' mission statements.

If foreign aid partly (or indeed perhaps only) responds to donor's strategic, political, and economic consideration, there is indeed no reason for foreign aid to be effective in promoting development of the recipients (Berthélemy \& Tichit, 2004). This is not to say that humanitarian motives and donor's strategic, political, and economic motives are contradictory, but if recipient need does not figure highly in the aid allocation decision it is likely that the impact of aid in promoting growth and development will be reduced.

The presence of donors' strategic, economic, and political motivations is likely to distort the aid transfer process and diminish the efficiency gains from the resource reallocation. For example, if aid is used to support so-called "friendly regimes" which are corrupt or authoritarian with ruling elites showing little interest in broad national development, there may be little correlation between aid and development. ${ }^{4}$ Secondly, the conditionality attached to the aid often embodies elements of strategic, economic, and political motivations of donors, which may diverge from recipients' own development

\footnotetext{
* The UK Department for International Development (DFID) supports policies, programs, and projects to promote international development. DFID provided funds for this study as part of that objective but the views and opinions expressed are those of the authors alone. Thanks to Bernard Walters and Yingqi Wei for comments on earlier drafts. Final revision accepted: December 7, 2010.
} 
strategies. The prescriptions of the IMF, World Bank, and other bilateral donors, in the form of stabilization and structural adjustment programs (SAPs) are often based on proglobalization and market liberalization ideologies (Mosley et al., 1995). Although such aid may promote the spread of donor-supported capitalism and open up the recipient's market to donor commercial interests, the developmental impact of program loans remains controversial. Strategic- and politically-oriented transfer may also bring volatility to the recipient's capital market. As Hayter and Watson (1985, p. 214) alleged, it is common that bilateral donors and the World Bank "intervene, or attempt to intervene, in the policies of a country with political objectives, but cease to lend when their efforts have little chance of succeeding." Such volatility and uncertainty of aid receipts may well undermine aid effectiveness.

Given the importance of the above debates and controversies, this paper seeks to investigate the factors that influence the aid allocations of bilateral donors and multilateral organizations. There are already a large number of empirical studies on aid allocation, McGillivray and White (1993), Berthélemy (2006a) and Dollar and Levin (2006) provide excellent surveys and methodological critique of such work. Our study can be distinguished from existing studies in three respects. First of all, it is based on an explicit economic model. Secondly, a panel data approach is adopted with explicit treatment of recipient and year effects. The dataset covers a large number of recipients (153 countries) and a relatively long period of time (1966-2008). Thirdly, the study is motivated by a particular subset of questions. The international hegemony of the United States and the replacement of the Cold War by the War on Terror mean that the allocation of United States aid may well be particularly motivated by strategic donor interest rather than recipient need. Indeed, recent material on the US Agency for International Development's (USAID) website seems quite forthright about this:

\footnotetext{
"The new century has brought new threats to US security and new challenges and opportunities for the national interest...Pre-empting threats and disasters is not the only reason that fostering development is in the U.S. interest. Successful development abroad generated diffuse benefits. It opens new more dynamic markets for U.S. goods and services. It generates more secure, promising environments for U.S. investment. It creates zones of order and peace where Americans can travel, study, exchange and do business safely. And it produces allies..."

http://www.usaid.gov/fani/overview (p. 2).
}

In March 2002, when the then US President George W. Bush proposed the first significant increase in US development assistance in a decade, he justified this at the United Nations Financing for Development in Monterrey, Mexico:

"We fight against poverty because hope is an answer to terror."

The U.S. Congress shares this view too.

\begin{abstract}
"A potential threat facing the United Sates after the Cold War may be spread of mass destruction, especially combined with political instability. ... a brief survey of the world's trouble spots showed a fairly striking correlation between economic malaise on the one hand and domestic unrest and political instability on the other. If the United States can address those problems by using its foreign aid to help to create economic opportunities and invest in human capital, then the chance of conflict may be reduced."

Congressional Budget Office study (1997).
\end{abstract}

Given these statements, it is interesting to see whether the allocation of the US aid to date shows greater responsiveness to donor self-interest than that of other bilateral and multilateral donors. If so, this historical practice may well become more dominant in the future given the changing nature of USAID's mission statement in the light of the War on Terror. In order to investigate this we make a comparison between the US aid and other bilateral aid.

There are also contrasting views on the allocation of multilateral aid. A standard line of argument, supported by a number of empirical studies (e.g., Maizels \& Nissanke, 1984; Rodrik, 1995), is that multilateral organizations, because they do not represent the interests of one particular nation, are more likely to respond to recipient need than donor interest in their aid allocation. On the other hand, it has been argued that two of the Washington-based multilateral organizations, the IMF and the World Bank, predominantly respond to the interests of the US administration in terms of both aid allocation and aid conditionality (Barro \& Lee, 2005; Frey \& Schneider, 1986; Thacker, 1999). A more recent study in World Development, Harrigan, Wang, \& El-Said (2006) also finds evidence that aid flows to the Middle East and North Africa from the IMF and World Bank were influenced by the geo-political interests of the United States. In order to investigate this further we now compare the US aid with other bilateral aid and aid from the multilaterals (we include all major multilaterals, not just the World Bank and IMF).

\section{THE AID ALLOCATION LITERATURE: A BRIEF REVIEW}

Development economists have always been interested in issues concerning the allocative patterns of foreign aid and its determinants. This has generated a large body of literature (see Berthélemy, 2006a; Dollar \& Levin, 2006; McGillivray $\&$ White, 1993). Studies can be categorized into three broad approaches: explanatory, descriptive, and prescriptive analyses (McGillivray \& White, 1993). The explanatory studies attempt to explain the observed allocation of aid; the descriptive studies seek to describe or evaluate aid allocation against normative criteria; and the prescriptive studies aim to prescribe the inter-recipient allocation of aid by calculating the amounts of aid each recipient should receive. For the purpose of this paper, we focus on the first group of studies, which has dominated the area so far.

Explanatory aid allocation studies can be categorized according to how they envisage the aid allocation process and hence the type of equations they estimate. McGillivray and White (1993) identify six non-mutually exclusive types of study: recipient need/donor interest; hybrid; bias; developmental; administrative/incremental and limited dependent variable. We review the different approaches below in order to help us decide upon and justify our own chosen methodology.

Recipient need/donor interest studies estimate two separate models of aid allocation - one containing variables to reflect recipient need and one containing variables to reflect donor interest (early well-known examples include Maizels \& Nissanke, 1984; McKinlay \& Little, 1977, 1978, 1979). The recipient need model is derived from the moral and humanitarian argument that absolutely poverty is intolerable and from the economic argument that if the marginal utility of income diminishes, total welfare will be increased by a redistribution of income from the rich to the poor. Hence, there is a moral imperative for governments of developed countries to provide aid because resources have been unequally distributed and/or there has been historical exploitation of poor country resources. As Chandrasekhar (1965, p. 5) argued, foreign aid 
is an economic problem, it may well be a political problem; but it is ultimately a moral problem ... it is a positive factor in the struggle of millions of human beings against the age-old enemies of hunger, poverty, disease, and ignorance." The Pearson Commission on International Development in 1969 (Commission on International Development, 1969) emphasized the moral and humanitarian motives for providing aid, and the Brandt Commission in 1980 and the Earth Summit in 2002 reiterated this view.

By contrast, the donor interest model is based on the hypothesis that donors seek to take advantage of the strategic and commercial gains they can derive from aid and hence allocate aid to pursue their self-interest. From the late 1960s, a number of scholars (e.g., Frank, 1969; Hayter, 1971, 1981; Hensman, 1971; Jalée, 1968) have argued that aid can be used to promote donors' own economic and foreign policy interests and to exercise their political power. The developed countries can exercise their financial muscles directly via their bilateral agencies as well as indirectly through multilateral organizations and international financial institutions (Riddell, 1987). Hence, the ultimate purpose for giving aid is to help spread donor values and ideas, such as capitalism or more recently globalization, and to perform the express functions of stabilizing pro-Western governments, for example, Egypt and Philippines, and containing the spread of communism, for example, South Korea and Vietnam. In general, it is found that the donor interest model performs better than the recipient need model.

A criticism of the donor interest/recipient need approach is that when the models are constructed, they are based separately either on recipient need or donor interest (e.g., McKinlay \& Little, 1978, 1979; Wittkopf, 1973). There is no ground for assuming that the aggregate allocation of aid is purely based on just one set of motives, that is, either donor interest or recipient need. As a result, there is model specification bias due to omitted variables. The correct option should be to adopt the so-called "hybrid" models, which estimate an aid allocation equation containing two sets of variables reflecting both the recipient's needs and donor's interests (as done by Bowles (1987), Feeny and McGillivray (2008), Levitt (1968), Poe and Sirirangsi (1993), and Wittkopf (1972)). This type of model has tended to dominate the literature so far.

There are a small number of studies adopting the "biases" approach. These focus on two biases in aid allocation: the population bias and the middle-income bias. The population bias exists when there is an inverse relationship between aid per capita and size of the recipient measured by population. There are a number of possible explanations for the existence of this bias. First of all, specialization in the production process caused by economies of scale induces small countries to trade a high percentage of their specialized output and import a great deal of their non-specialized products. If business groups and sections of the donor bureaucracy concerned with trade promotion are particularly active, small countries with a high percentage of trade shares are likely to be favored by donors.

Second, the population bias can be explained by donors' geo-political interests. As population increases, the marginal political benefit to the donor decreases (Dowling \& Hiemenz, 1985). As Isenman (1976, p. 632) notes “... a very small country can potentially help or hurt a donor by its vote in UN or its voice in other international fora." Since aid allocation is a process established on a nation-by-nation basis rather than a population basis, it offers the small country a bargaining advantage. Consequently, this would push donors to spread their aid across a large number of countries in order to maximize as many good relations with recipients as possible (Arvin
\& Drewes, 2001). ${ }^{5}$ Small countries are also chosen by the donors, since the cost of exerting political leverage is lower in less populous countries and small countries may be more likely to accept the conditionality attached to the aid programs. As a result, aid dependency may be higher in small countries than in large countries. Third, it has been argued that the capacity of large countries to absorb additional amounts of aid is questionable as technical and administrative expertise often present bottlenecks to effective utilization of additional aid (Dowling \& Hiemenz, 1985).

The middle-income bias refers to the observation that poorer countries tend to receive less aid, however, once a certain income threshold has been reached, aid and income per capita become positively correlated (Alesina \& Dollar, 2002; Dowling \& Hiemenz, 1985; Isenman, 1976). The middleincome bias may creep in mainly due to the economic and political importance of the middle-income countries (e.g., bilateral trade is one consideration) or their relatively welldeveloped bureaucracies which can administer the aid and make the aid more effective (Dowling \& Hiemenz, 1985). ${ }^{6}$

Bureaucratic/incremental models hypothesize that marginal incrementalism or bureaucratic inertia influence aid allocation and hence estimate allocation equations containing variables such as the preceding year's allocations (Feeny \& McGillivray 2008; Gang \& Khan, 1990; Gulhati \& Nallari, 1988). Developmental models (e.g., Davenport, 1970) use developmental variables alone to explain aid allocation — as such they are similar to recipient need models.

Since the 1990s, two advances have emerged in the aid allocation literature. One is the panel data approach in which the relationship between donor and recipient is captured by the fixed-effects coefficients. The other is the recognition of the truncated or censored nature of the dependent variable (the Limited Dependent Variable Approach) in aid allocation studies.

Trumbull and Wall (1994) argue that existing studies based on cross-sectional data do not account for the heterogeneity of recipient countries, and that they are of limited use if there are unobserved recipient-specific variables that correlate with one or more of the explanatory variables. Variables of this type could be those geopolitical factors, such as recipients' colonial histories, their strategic value to donors, their political regimes or their geographical location. A panel dataset possesses several major advantages over either cross-sectional or time series data. For example, it gives more informative data, more variability, less collinearity among the variables, more degrees of freedom, and higher efficiency (Greene, 2007). Moreover, the groupwise heteroskedasticity can be substantially reduced. The panel data can also be used for the limited dependent variable approach (LDVA), such as the Probit and Tobit models. Most of the LDVA can be applied in a panel data setting when the random-effects are introduced. For the Count and Tobit models, fixed-effects can be introduced as well (Greene, 2007). ${ }^{7}$

Limited dependent variable models address the issue of country eligibility for aid, which is an important part of the aid allocation decision. McGillivray (2003) argues, given the censored nature of the dependent variable in aid allocation which is not properly recognized in the existing empirical literature, that it is likely that most studies have reported biased results, consequently, much of popular opinion on aid allocation may well be misleading. A more appropriate approach would be to use limited dependent variable techniques such as sample selection models. These portray aid allocation as a two stage process, that is, "Yes/no" (stage one deciding on eligibility) and "if yes, how much" (stage two). Such models can help to 
explain why some countries receive no aid at all as well as the amounts allocated to those deemed eligible. Examples of this approach include Cingranelli and Pasquarello (1985), Dudley and Montmarquette (1976), McGillivray and Oczkowski (1991), and Poe (1992). These studies treat aid allocation as a utility maximizing problem and often use Probit and then OLS to explain the eligibility and amount decisions, respectively.

More recent studies have adopted a Tobit model, for example, Alesina and Dollar (2002), McGillivray and White (1993) and Thiele, Nunnenkamp, and Dreher (2007). This model treats the decision on eligibility and the decision on amounts as a single simultaneous process. However, there are a number of potential difficulties with this approach. The Tobit model relies crucially on the assumptions of normality and homoskedasticity in the underlying latent variable model. If any of these fail to hold, the Tobit model is meaningless (Greene, 2007). Moreover, the Tobit model imposes the condition that the relationship generating the ones and zeros (eligible or ineligible) is the same as the process that produces the positive values (in terms of allocated amounts), which may not be the case in the aid allocation process. One example is the effect of population, which may have a positive effect on eligibility due to the administrative costs (Dudley \& Montmarquette, 1976) and a negative effect on the amount of aid allocated due to the population bias. This would require the coefficient on population to have different signs, which is impossible in the Tobit model because they are the same coefficient (Greene, 2007).

In this regard, it is argued in the literature that Heckman's two-step method may be appropriate. The first step is to estimate a Probit model which determines the eligibility of receiving aid, and in the second step, a linear model explaining aid commitments is estimated based only on strictly positive observations and the inverse Mills ratio obtained from the first step to correct selection bias. However, Lewis (1986, p. 59) notes that estimates using this approach seem to exhibit much greater variability across studies than those using simpler techniques. This may be due to a number of factors. First of all, the parameters of the model appear to be sensitive to the presence of heteroskedasticity or non-normality. Secondly, it is difficult to find variables that affect the probability of receiving aid and do not enter the model in the second step.

The above survey of the empirical aid allocation literature illustrates the simple truth, as McGillivray and White (1993) have argued, that the aid allocation process is complex and no one knows exactly how it works. In the real world, donor-recipient relations are likely to involve the interplay of bureaucratic, political, commercial, developmental, and other factors, and these are rarely sufficiently appreciated and accounted for in many aid allocation models. ${ }^{8}$ As a result there are huge variations in the models employed in aid allocation studies, and as such it is unsurprising that the results generated from existing work also vary and sometimes even contradict each other.

The above critique of aid allocation studies has helped shape the methodological approach we employ in our study. Firstly, we feel it is important to formulate a theoretical model of the aid allocation process before drawing on empirical arguments. Few papers have done this with the exception of Dudley and Montmarquette (1976), Trumbull and Wall (1994) and Feeny and McGillivray (2008). The model formulates, albeit in a limited way, our view of what constitute the key factors in a complex real world aid allocation process. From this we derive an econometric model for testing which is essentially a hybrid model incorporating both donor interest and recipient need. We use a panel dataset covering the period 1966-2008 for 153 countries. We are mainly concerned with countries that receive a positive amount of aid. However, in light of the above discussion of truncated variables we also run the Probit and Tobit regressions using the same set of variables to see if the findings are consistent with the regressions that used only the positive values of aid per capita.

\section{THE MODEL}

In order to model the aid allocation process, the first step should be to define the nature of aid. According to the Keynesian argument for international assistance, developing countries accept foreign aid because most of them cannot generate sufficient savings to relieve investment bottlenecks. Developed donor countries may also gain from such transfer when the rates of return on aid are higher than the marginal productivity of capital in their own countries and lower than the marginal productivity of capital in the developing recipient countries. As such, foreign aid can be termed an international public good because the donor countries can benefit from the total welfare raised by aid. The implication is that donor countries can benefit from its social returns while the recipients benefit from its private returns as well as its social returns. The aid allocation model that follows is based on the assumption that donors derive welfare or utility from the positive impacts of aid in the recipient country and they aim to maximize this welfare. 9

Supposing donors believe that ODA is put to good use by recipient governments, each year a donor country allocates its ODA budget among the $m$ recipients, with the objective of maximizing the total impact of ODA to the recipients. Let $H$ be the sum of the impacts of the donor's aid on its own welfare, the problem faced by the donor is ${ }^{10}$

Maximize $H=\sum_{j=1}^{m} \theta_{j} H_{j}=\sum_{j=1}^{m} \theta_{j} n_{j} h_{j}\left(n_{j}, a_{j}, y_{j}, p_{j}\right)$

where $H_{j}$ is the subjectively measured impact on the recipient $j$; $h_{j}$ is the subjectively measured impact on an individual citizen in the recipient $j$ (identical within the country); $n_{j}$ is the population of the recipient $j ; a_{j}$ is the aid per capita received by the recipient $j ; y_{j}$ is the GDP per capita of the recipient $j ; p_{j}$ is an index measure of the policy environment in the recipient $j ; \theta_{j}$ is a rate of return to the donor from the impact on the recipient $j$. This is determined by economic, political, and other linkages between the donor and recipient.

The above model is based on the following assumptions. $y_{j}$ appears in the equation since, other things being equal, the poorer the recipient country, the more aid is needed and the more benefit the country will derive from an additional unit of aid. $p_{j}$ is included based on the hypothesis that the better the policy instruments the recipient government employs, the more benefit the country will derive from an additional unit of aid (Burnside \& Dollar, 2000). In giving aid, the recipient's population $n_{j}$ can be important. If two countries have the same level of $y_{j}$, it is the smaller country that will have the larger financial gap in per capita terms such that the impact of aid per capita will decrease with population size. In summary, the impact of aid on each individual in the recipient $j$ will be an increasing function of aid per capita and a decreasing function of $j$ 's GDP per capita and of population. The donor country can only benefit from a proportion of this impact and the 
rate may depend on the social, economic, as well as political linkages. These assumptions can be represented as follows:

$\frac{\partial h_{j}}{\partial a_{j}}>0, \quad \frac{\partial h_{j}}{\partial y_{j}}<0, \quad \frac{\partial h_{j}}{\partial p_{j}}>0, \quad \frac{\partial h_{j}}{\partial n_{j}}<0$

The donor has five options to increase the total impact of its foreign aid, including increasing the magnitude of aid, switching funds from a relatively rich country to a relatively poor country, from a country with bad policies to one with good policies, from a less populous country to a more populous country, ${ }^{11}$ or from a country with less linkages with itself to one with more linkages with itself.

We can specify the aid impact function on recipient $j$ as the following:

$$
\begin{aligned}
H_{j} & =h_{j} * n_{j}=\frac{a_{j}^{\alpha} p_{j}^{\delta}}{n_{j}^{\beta} y_{j}^{\gamma}} * n_{j}, \quad 0<\alpha, \beta, \gamma, \delta<1 ; \quad \alpha+\beta \\
& <1 ; \quad \alpha+\gamma<1,
\end{aligned}
$$

The assumption of $\alpha+\gamma<1$ rules out the possibility that each individual can benefit from giving up one unit of income for an additional unit of aid (holding other things constant) ${ }^{12}$ and the assumption of $\alpha+\beta<1$ indicates that there is an effect of economies of scale. ${ }^{13}$

Finally, the donor country is limited by its budget constraint

$\sum_{j=1}^{m} a_{j} n_{j}=B$

Substituting (3) and (5) into (1) and then solving the constraint problem faced by the donor

$$
\text { Maximize } \begin{aligned}
L & =\sum_{j=1}^{m} \theta_{j} n_{j} \frac{a_{j}^{\alpha} p_{j}^{\delta}}{n_{j}^{\beta} y_{j}^{\gamma}}+\lambda\left(B-\sum_{j=1}^{m} a_{j} n_{j}\right) \\
& 0<\alpha, \beta, \gamma, \delta<1 ; \quad \alpha+\beta<1 ; \quad \alpha+\gamma<1
\end{aligned}
$$

The first order conditions are

$$
\begin{aligned}
\frac{\partial H}{\partial a_{j}} & =\sum_{j=1}^{m} \frac{\alpha \theta_{j} a_{j}^{\alpha-1} p_{j}^{\delta}}{n_{j}^{\beta-1} y_{j}^{\gamma}}-\sum_{j=1}^{m} \lambda n_{j}=0 \quad 0<\alpha, \beta, \gamma, \delta<1 ; \\
\alpha & +\beta<1 ; \quad \alpha+\gamma<1 \\
\frac{\partial H}{\partial \lambda} & =B-\sum_{j=1}^{m} a_{j} n_{j}=0
\end{aligned}
$$

Equating (6) and (7) gives the optimal allocation of aid per capita for each recipient

$a_{j}=\left[\frac{\alpha \theta_{j} p_{j}^{\delta}}{\lambda n_{j}^{\beta} y_{j}^{\gamma}}\right]^{1 /(1-\alpha)}$

Taking the log transformation, we have

$$
\begin{aligned}
\log a_{j}= & \frac{1}{1-\alpha} \log \alpha+\frac{1}{1-\alpha} \log \theta_{j}+\frac{-1}{1-\alpha} \log \lambda \\
& +\frac{-\beta}{1-\alpha} \log n_{j}+\frac{-\gamma}{1-\alpha} \log y_{j}+\frac{\delta}{1-\alpha} p_{j} \\
j & =1, \ldots, m
\end{aligned}
$$

Eqn. (8) provides the basic model, which will be estimated and tested in the next section. However, before proceeding with the regression analysis, we first elaborate on a number of issues concerning the representation of aid impact in our model.

\section{(a) Donor benefits versus recipient benefits}

Consider a scenario where all the recipient countries are homogenous in terms of population, GDP per capita, and policy environment. A donor can choose between two approaches to its aid allocation: one is to consider linkages $\theta_{j}$ between donor and recipient, the other is to ignore such linkages. The impact of the first strategy on recipients can vary, some recipients will benefit more and others less. Note $\frac{\partial h_{j}}{\partial a_{j}}>0$ and $0<\alpha<1$ $\left(y_{j}=y_{k}, n_{j}=n_{k}\right.$ and $\left.p_{j}=p_{k}, j, k \in m\right)$. The recipients as a whole would gain less when the donor adopts the first strategy since resources may be shifted from more productive countries to less productive countries. If all recipients are equally important (in terms of linkages) to the world as a whole but vary in terms of their importance to a specific donor, the world as a whole would also gain less when the first strategy is adopted by the donor.

\section{(b) Comparison among donors}

In the previous section, only one donor is considered. Now, we assume that there are two identical donors, but they differ in their linkages to the recipients. One donor has the same level of linkages as those applied to the world with all the recipients, the other's linkages with recipients varies. In order to maximize the total impact of its aid allocation on its own welfare, the first donor would simply distribute its aid equally among recipients, and the second would put more emphasis on the linkages. It is clear that if both donors try to achieve their objectives, the benefit to the world generated from the first donor's aid is larger than that from the second. As a result, in the empirical literature on aid allocation, when comparisons are made between donors based on recipient need model, it is likely that $R^{2}$ s are higher for donors, such as Denmark and Sweden, but lower for the United States since the recipient need model fits well with the Nordic countries' emphasis on the developmental and humanitarian needs of developing countries. It is also likely that the standard deviation of the fixed-effects coefficient would be lower for the former and higher for the latter when the fixed-effects panel approach is adopted.

\section{EMPIRICAL MODEL AND DATA}

Eqn. (8) can only be tested when one can find an appropriate measure for each variable. However, there is no generally agreed measurement for the linkage between donor and recipient $\left(\theta_{j}\right)$. The linkage could be colonial ties, strategic alliance, cultural similarity, proximity in terms of geographic location, commercial links, and so on. In order to overcome this problem, following Trumbull and Wall (1994), we adopt the panel data approach and introduce fixed-effects to take account of the donor-recipient linkage. ${ }^{14}$

By introducing a time subscript, adding the error term and replacing the parameters with coefficients in Eqn. (8), we obtain the following equation for estimation:

$$
\begin{aligned}
& \log a_{j t}=b_{0}+b_{j}+b_{t}+b_{1} \log n_{j t}+b_{2} \log y_{j t}+b_{3} p_{j t}+e_{j t} ; \\
& j=1, \ldots, m ; t=1, \ldots T
\end{aligned}
$$

where $b_{t}=\frac{-1}{1-\alpha} \log \lambda_{t}, b_{j}=\frac{1}{1-\alpha} \log \theta_{j}, b_{1}=\frac{-\beta}{1-\alpha}, b_{2}=\frac{-\gamma}{1-\alpha}, b_{3}=\frac{\delta}{1-\alpha}$ and $\lambda_{t}^{*}$ is the equilibrium shadow value of aid. Note $-1<b_{1}<0,-1<b_{2}<0$ and $b_{3}>0$, Since, $0<\alpha, \beta, \delta$, $\gamma<1 ; \alpha+\beta<1$ and $\alpha+\beta<1$. In Eqn. (8), $a_{j t}, n_{j t}$, and $p_{j t}$ 
are country $j$ 's ODA commitment per capita in year $t, j$ 's population in year $t$ and $j$ 's average growth rate of year $t-2$ to $t$, respectively. Note our measurement of the policy environment is different from the one employed by Burnside and Dollar (2000), which is a composite index of inflation, budget surplus, and openness based on the growth regression. Their index only covers three policy instruments and considers short-run effects; while ours is an ex-post measure of the medium term policy environment (proxied by the growth performance). ${ }^{15}$

The ODA commitment data are obtained from the OECD's online database while data for the other variables are taken from the World Bank Development Indicators (WDI) CDROM. Detailed definitions of variables and data sources are given in Appendix 1 and descriptive statistics and the correlation matrix for the variables are given in Appendix 2. The dataset used covers 153 countries over the period 1966-2008.

Using Eqn. (8), we investigate and contrast the allocation of USA bilateral aid and other major donors including Canada, France, Italy, Japan, and United Kingdom to see whether the United States, given its geo-political hegemony, displays specific behavior in its aid allocation. We also contrast bilateral ODA with multilateral ODA allocations to see if there are differences in allocation. One might question whether Eqn. (8) is applicable to the multilateral aid since it is based on a model that only takes account of one donor's behavior. However, if coupled with the assumptions that all the multilateral aid donors use the same subjective measure of the impact of ODA to a recipient and each recipient is equally important to all the donors within the group (see Trumball and Wall (1994)) Eqn. (8) is readily applicable. ${ }^{16}$
It is well understood that generally, a panel dataset can be estimated in three ways, depending on whether the individual cross-sectional effects are considered to be constant, fixed, or random. The corresponding statistical models are OLS, fixed effects (FE), or random effects (RE). These three models have their own advantages and disadvantages. The OLS model is simple, but the assumption that the individual-specific effects do not differ is often too strong to hold in most cases. The FE model allows variation in these effects and does not impose the strict condition that regressors are uncorrelated with fixed effects, but including dummy variables as extra regressors make it less efficient than the RE model because of the loss of degrees freedom. Finally, the RE model relegates the individual-specific effects into the error term and assumes that they are uncorrelated with the regressors. Violation of this assumption may cause the RE model to produce biased and inconsistent estimates. There is no rule of thumb for choosing among the three models. The choice is largely dependent on three factors: the model specification, the sample size, and the statistical testing.

Three tests are usually applied to identify the best statistical model. The likelihood ratio (LR) statistic is applied to test the fixed effects model versus OLS model, with a high value favoring country effects over OLS. The Lagrange multiplier (LM) statistic is applied to test the country and year random (\&fixed) effects model versus OLS model, with a high value favoring random (\&fixed) effects model over OLS model. The Hausman statistic is applied to test fixed effects model versus random effects model, and a high value favors fixed effects model over random effects model. These test statistics are supplied at the bottom of relevant tables.

Table 1. Estimation results based on Eqn. (8)

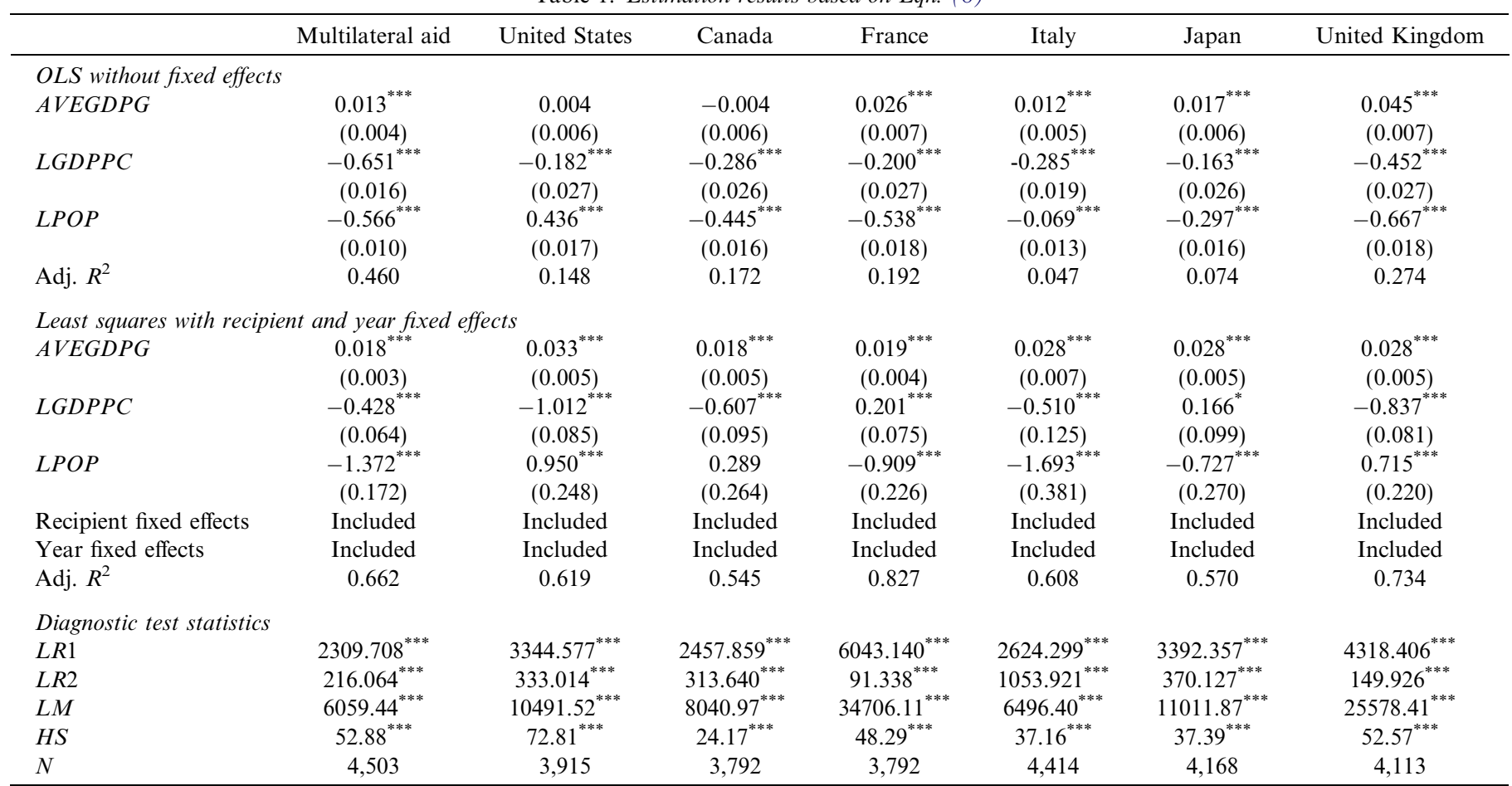

Notes: 1. Recipient and year fixed effects are not reported. 2. Standard errors are in parentheses. 3. ***, **, and * indicate that the coefficient is significantly different from zero at the $1 \%, 5 \%$, and $10 \%$ levels, respectively. 4 . The likelihood ratio (LR1) statistic is applied to test the recipient and year fixed effects versus OLS, high value favors two way effects model over OLS. 5. The likelihood ratio (LR2) statistic is applied to test the recipient and year fixed effects versus recipient fixed effects only, high value favors two-way effects model over recipient fixed effects. 6 . The Lagrange multiplier (LM) statistic is applied to test the recipient and year effects versus OLS, high value favors random (\&fixed) effects model over OLS. 7. The Hausman statistic is applied to test fixed effects versus random effects, high value favors fixed effects over random effects model. 
Table 2. List of countries with smallest and largest fixed-effect coefficients based on Eqn. (8) and Standard deviations (s.d.) And correlations of fixed-effect coefficients

\begin{tabular}{|c|c|c|c|c|c|c|c|}
\hline & Multilateral aid & USA & Canada & France & Italy & Japan & United Kingdom \\
\hline \multicolumn{8}{|c|}{ Least favored recipients } \\
\hline & Palau & India & Saudi Arabia & Marshall Islands & Palau & Bermuda & China \\
\hline & Bermuda & Viet Nam & Iran & Bermuda & Kiribati & Bahamas & India \\
\hline & Brunei & Nigeria & China & Micronesia & Marshall Islands & Libya & Congo, Dem. Rep. \\
\hline & Macao & Iran & Uzbekistan & Macao & Barbados & Kuwait & Uzbekistan \\
\hline & Kiribati & Brazil & Korea & Antigua and Barbuda & Tonga & Cyprus & Burkina Faso \\
\hline & Marshall Islands & Indonesia & India & Bahamas & Samoa & Equatorial Guinea & Philippines \\
\hline & Micronesia & Saudi Arabia & Nigeria & Kiribati & Dominica & French Polynesia & Morocco \\
\hline & Aruba & Bangladesh & Kyrgyz Republic & Belize & St. Kitts-Nevis & Macao & Brazil \\
\hline & French Polynesia & Congo, Dem. Rep. & Moldova & Barbados & Comoros & Belarus & Korea \\
\hline & $\begin{array}{l}\text { Antigua and } \\
\text { Barbuda }\end{array}$ & Ethiopia & Syria & Palau & St. Lucia & New Caledonia & Iran \\
\hline \multicolumn{8}{|c|}{ Most favored recipients } \\
\hline & Turkey & Grenada & $\begin{array}{l}\text { St.Vincent \& } \\
\text { Grenadines }\end{array}$ & Mali & Tunisia & Malaysia & St.Vincent \& Grenadines \\
\hline & Viet Nam & Cyprus & Seychelles & Tunisia & Morocco & India & Grenada \\
\hline & Ethiopia & Bahamas & Guyana & Madagascar & Turkey & Pakistan & Vanuatu \\
\hline & South Africa & Antigua and Barbuda & Belize & Algeria & Indonesia & Korea & Bermuda \\
\hline & Brazil & Seychelles & St. Lucia & Cameroon & Mozambique & China & Belize \\
\hline & Indonesia & Israel & Grenada & French Polynesia & Ethiopia & Sri Lanka & Antigua and Barbuda \\
\hline & Egypt & St. Kitts-Nevis & Bermuda & Senegal & India & Bangladesh & Kiribati \\
\hline & Pakistan & Micronesia & Barbados & Morocco & Argentina & Thailand & Dominica \\
\hline & Bangladesh & Marshall Islands & St. Kitts-Nevis & New Caledonia & Brazil & Philippines & Seychelles \\
\hline & India & Palau & Dominica & Cote d'Ivoire & Egypt & Indonesia & St. Kitts-Nevis \\
\hline s.d. & 2.077 & 3.516 & 2.057 & 2.391 & 2.729 & 1.947 & 3.312 \\
\hline United States & -0.745 & & & & & & \\
\hline Canada & -0.503 & 0.760 & & & & & \\
\hline France & 0.675 & -0.633 & -0.391 & & & & \\
\hline Italy & 0.792 & -0.550 & -0.358 & 0.611 & & & \\
\hline Japan & 0.573 & -0.471 & -0.397 & 0.301 & 0.282 & & \\
\hline United Kingdom & -0.702 & 0.802 & 0.793 & -0.635 & -0.572 & -0.440 & \\
\hline
\end{tabular}




\section{EMPIRICAL RESULTS}

Table 1 presents the results from pooled regression (OLS) and two-way fixed effects panel regression based on Eqn. (8) for different donors, more specifically, multilateral organizations, United States, Canada, France, Italy, Japan, and United Kingdom. Diagnostic test results indicate that the two-way (country and year) fixed effects models are statistically better models than the others. Our discussion below will, therefore, focus on the statistically preferred two-way fixed effects models (least squares with recipient and year fixed effects).

Most results of the two-way fixed effects models in Table 1 are in line with expectations. Coefficients on growth rate (AVEGDPG) are consistently positive and statistically significant, indicating that donors reward recipients with a good policy environment. The coefficients on GDP per capita (LGDPPC), apart from France and Japan aid regressions, have a negative sign and are statistically significant, suggesting that donors (multilateral donors, United States, Canada, Italy, and United Kingdom) respond to recipient need in their aid allocations. This is consistent with the results of Feeny and McGillivray (2008) who, like us, develop an aid allocation theoretical model for empirical testing. The magnitude on LGDPPC is greater than 1 in the USA regression ${ }^{17}$ which is larger than those in other regressions, indicating once other factors (including donor interests) are controlled for, United States puts greater emphasis on recipient need than others. The coefficients on population (LPOP) are rather mixed. Recipients with large population appear to attract less aid per capita from multilateral organizations, France, Italy, and Japan. On the other hand, those with large population seem to receive more United States and United Kingdom aid per $\mathrm{ca}$ pita and recipient population size appears to have little impact on Canadian aid. This suggests that aid from different donors exhibits different patterns of population bias and the finding is generally consistent with those in other aid determinants studies (e.g., Berthélemy \& Tichit, 2004).

Although the above results suggest that most donors have responded to good policy environment and recipient need, we are also interested in knowing to what extent have they responded to these factors? One way to answer this question is to look at the adjusted $R^{2}$ from the OLS regressions. These statistics explain how much variation is explained by the variables (AVEGDPG, LGDPPC and LPOP). The adjusted $R^{2}$ for the multilateral aid, United States, Canada, France, Italy, Japan, and United Kingom regressions are 0.460, 0148, 0.172, $0.192,0.047,0.074$, and 0.274 respectively. It is clear that bilateral donors put less emphasis on good policy environment and recipient need than multilateral donors do, and United States and Japan, the largest and second largest donors allocate a low proportion of their aid based on good policy environment and recipient need.

The donor-recipient specific effects are of interest here since they capture the linkages between donor and specific recipient's which might reflect such factors as long term strategic relations, economic linkages, colonial ties, geographic proximity, and culture or language similarities. If a donor puts more weight on linkages, that is, donor interest, rather than recipient need, the standard deviation would be larger. The standard deviation (s.d.) of the fixed effects coefficients is reported at the bottom of Table 2. Among these statistics, the United States has the higher figure suggesting that the United States places more emphasis on the donor interest inter-linkages than other bilateral and multilateral donors. Following the s.d., the correlation matrix of fixed effects is given at the bottom of Table 2 . The correlations between the USA-recipients fixed effects, UK-recipients fixed effects, and Canada-recipients fixed effects are all larger than 0.75, indicating the presence of AngloAmerican relationships in aid allocation. The other three bilateral donors, France, Italy, and Japan seem to distance themselves from the Anglo-American pact but share similar interests to those of multilateral donors.

Since this dataset covers 153 countries, it would be very demanding to discuss all the recipient-specific effects for all the donors. Table 2 reports the most and least favored recipients for each donor. Take the USA as an example, large positive country fixed effects indicate the USA favors a number of small states including Grenada, Cyprus, Bahamas, Antigua and Barbuda, Seychelles, Israel, St. Kitts-Nevis, Micronesia, Marshall Islands and Palau. This is not surprising given the extremely close relationship between the USA and Israel particularly since the signing of the Camp David Accord in the late 1970s, and the past importance of many of the small states in the Caribbean Basin to the USA's fight against communism in its back yard.

As mentioned at the start of this paper, one of the motivations of our research is to speculate whether, in light of the current War on Terror, future aid allocations, especially on the part of the USA, are likely to become more influenced by geo-political concerns. For example, aid flows may become more geared towards supporting pro-Western regimes in the Middle East and North Africa (MENA). If we can establish that such practices are already embedded in the geographical allocation of aid then we can speculate that this may well intensify in years to come. Hence, in looking at the donor and recipient country fixed effects, we shall concentrate the

Table 3. Rankings of MENA countries according to fixed-effect coefficients based on Eqn. (8)

\begin{tabular}{|c|c|c|c|c|c|c|c|}
\hline & Multilateral Aid & United States & Canada & France & Italy & Japan & United Kingdom \\
\hline Most favored to Least & Egypt & Israel & Lebanon & Morocco & Egypt & Egypt & Jordan \\
\hline \multirow[t]{12}{*}{ favored countries } & Turkey & Jordan & Jordan & Algeria & Turkey & Jordan & Lebanon \\
\hline & Morocco & Lebanon & Tunisia & Tunisia & Morocco & Morocco & Iraq \\
\hline & Sudan & Iraq & Israel & Egypt & Tunisia & Turkey & Sudan \\
\hline & Algeria & Egypt & Morocco & Lebanon & Algeria & Yemen & Yemen \\
\hline & Tunisia & Tunisia & Iraq & Turkey & Lebanon & Tunisia & Tunisia \\
\hline & Yemen & Morocco & Egypt & Syria & Sudan & Syria & Turkey \\
\hline & Lebanon & Turkey & Algeria & Yemen & Iraq & Sudan & Israel \\
\hline & Syria & Yemen & Sudan & Jordan & Iran & Iran & Egypt \\
\hline & Jordan & Sudan & Turkey & Sudan & Jordan & Algeria & Syria \\
\hline & Iraq & Syria & Yemen & Iran & Yemen & Lebanon & Algeria \\
\hline & Iran & Algeria & Syria & Iraq & Syria & Israel & Iran \\
\hline & Israel & Iran & Iran & Israel & Israel & Iraq & Morocco \\
\hline s.d. & 1.104 & 3.488 & 1.882 & 1.486 & 1.467 & 1.767 & 1.930 \\
\hline
\end{tabular}


Table 4. Aid by sources

\begin{tabular}{|c|c|c|c|c|c|c|c|}
\hline & Multilateral aid & United States & Canada & France & Italy & Japan & United Kingdom \\
\hline$A V E G D P G$ & $\begin{array}{l}0.017^{* * *} \\
(0.005)\end{array}$ & $\begin{array}{l}0.038^{* * *} \\
(0.008)\end{array}$ & $\begin{array}{l}0.027^{* * *} \\
(0.009)\end{array}$ & $\begin{array}{l}0.008 \\
(0.006)\end{array}$ & $\begin{array}{l}0.041^{* * *} \\
(0.010)\end{array}$ & $\begin{array}{l}0.022^{* * *} \\
(0.008)\end{array}$ & $\begin{array}{l}0.038^{* * *} \\
(0.007)\end{array}$ \\
\hline$A V E G D P G * D U M 90$ & $\begin{array}{l}0.000 \\
(0.007)\end{array}$ & $\begin{array}{l}-0.012 \\
(0.010)\end{array}$ & $\begin{array}{l}-0.015 \\
(0.011)\end{array}$ & $\begin{array}{l}0.016^{* *} \\
(0.008)\end{array}$ & $\begin{array}{l}-0.027^{* *} \\
(0.013)\end{array}$ & $\begin{array}{l}0.011 \\
(0.010)\end{array}$ & $\begin{array}{l}-0.025^{* * *} \\
(0.009)\end{array}$ \\
\hline$L G D P P C$ & $\begin{array}{l}-0.281^{* * *} \\
(0.071)\end{array}$ & $\begin{array}{l}-0.790^{* * *} \\
(0.097)\end{array}$ & $\begin{array}{l}-0.682^{* * *} \\
(0.107)\end{array}$ & $\begin{array}{l}0.095 \\
(0.084)\end{array}$ & $\begin{array}{l}-0.308^{* *} \\
(0.140)\end{array}$ & $\begin{array}{l}0.235^{* *} \\
(0.109)\end{array}$ & $\begin{array}{l}-0.611^{* * *} \\
(0.089)\end{array}$ \\
\hline$L G D P P C * D U M 90$ & $\begin{array}{l}-0.129^{* * *} \\
(0.028)\end{array}$ & $\begin{array}{l}-0.202^{* * *} \\
(0.045)\end{array}$ & $\begin{array}{l}0.079^{*} \\
(0.048)\end{array}$ & $\begin{array}{l}0.073^{* *} \\
(0.030)\end{array}$ & $\begin{array}{l}-0.120^{* *} \\
(0.054)\end{array}$ & $\begin{array}{l}-0.009 \\
(0.040)\end{array}$ & $\begin{array}{l}-0.225^{* * *} \\
(0.038)\end{array}$ \\
\hline$L P O P * D U M 90$ & $\begin{array}{l}-0.066^{* * *} \\
(0.017)\end{array}$ & $\begin{array}{l}0.003 \\
(0.026)\end{array}$ & $\begin{array}{l}0.164^{* * *} \\
(0.026)\end{array}$ & $\begin{array}{l}-0.021 \\
(0.019)\end{array}$ & $\begin{array}{l}-0.044 \\
(0.037)\end{array}$ & $\begin{array}{l}-0.179^{* * *} \\
(0.025)\end{array}$ & $\begin{array}{l}0.168^{* * *} \\
(0.022)\end{array}$ \\
\hline $\begin{array}{l}\text { Recipient fixed effects } \\
\text { Year fixed effects } \\
\text { Adi } R^{2}\end{array}$ & $\begin{array}{l}\text { Included } \\
\text { Included } \\
0662\end{array}$ & $\begin{array}{l}\text { Included } \\
\text { Included } \\
0619\end{array}$ & $\begin{array}{l}\text { Included } \\
\text { Included } \\
0.545\end{array}$ & $\begin{array}{l}\text { Included } \\
\text { Included } \\
0827\end{array}$ & $\begin{array}{l}\text { Included } \\
\text { Included } \\
0608\end{array}$ & $\begin{array}{l}\text { Included } \\
\text { Included } \\
0.57\end{array}$ & $\begin{array}{l}\text { Included } \\
\text { Included } \\
0734\end{array}$ \\
\hline Adj. $R^{2}$ & 0.662 & 0.619 & 0.545 & 0.827 & 0.608 & 0.57 & 0.734 \\
\hline
\end{tabular}

Notes: 1 . Recipient and year fixed effects are not reported. 2. Standard errors are in parentheses. $3 . * * *, * *$, and * indicate that the coefficient is significantly different from zero at the $1 \%, 5 \%$, and $10 \%$ levels, respectively. 4. The likelihood ratio (LR1) statistic is applied to test the recipient and year fixed effects versus OLS, high value favors two way effects model over OLS. 5. The likelihood ratio (LR2) statistic is applied to test the recipient and year fixed effects versus recipient fixed effects only, high value favors two-way effects model over recipient fixed effects. 6 . The Lagrange multiplier (LM) statistic is applied to test the recipient and year effects versus OLS, high value favors random (\&fixed) effects model over OLS. 7. The Hausman statistic is applied to test fixed effects versus random effects, high value favors fixed effects over random effects model.

Table 5. Tests of "middle-income bias" and "Bandwagon effect"

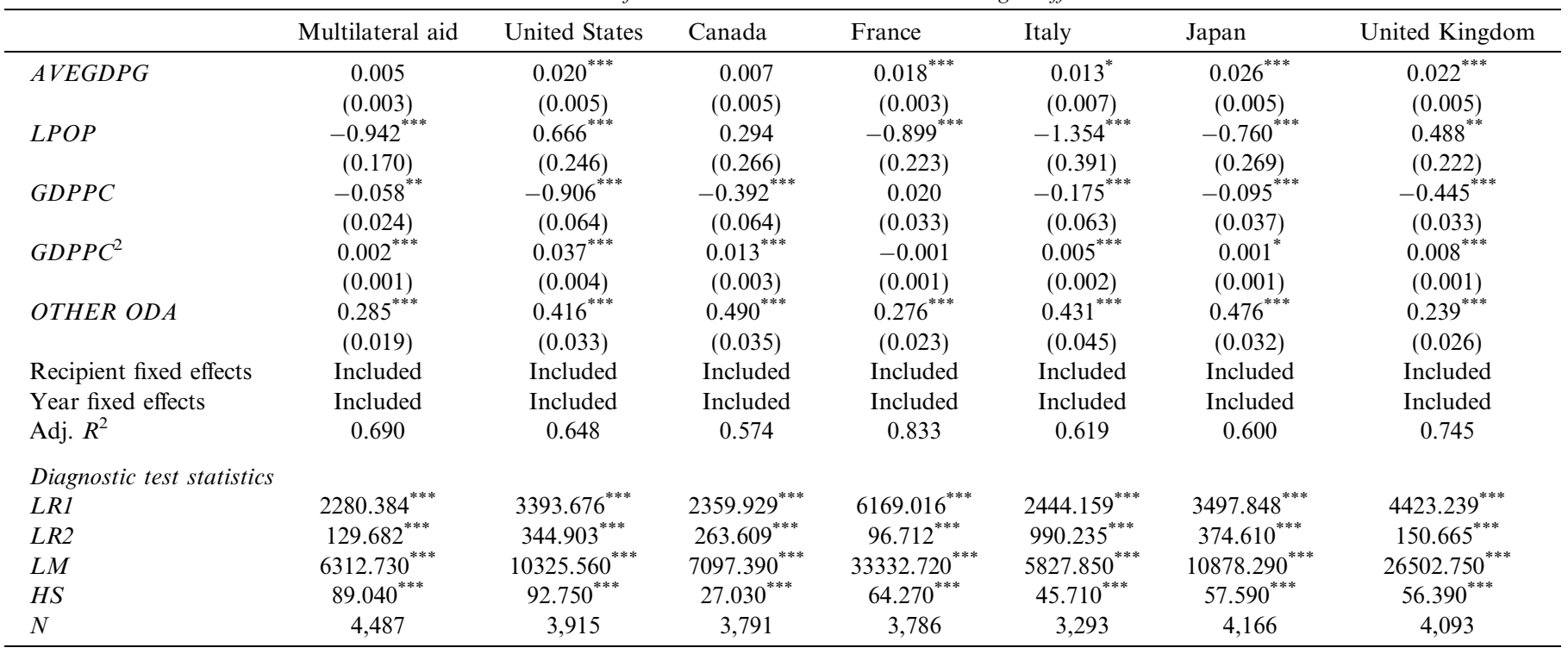

Notes: 1. Recipient and year fixed effects are not reported. 2. Standard errors are in parentheses. 3. ***, **, and * indicate that the coefficient is significantly different from zero at the $1 \%, 5 \%$, and $10 \%$ levels, respectively. 4 . The likelihood ratio (LR1) statistic is applied to test the recipient and year fixed effects versus OLS, high value favors two way effects model over OLS. 5. The likelihood ratio (LR2) statistic is applied to test the recipient and year fixed effects versus recipient fixed effects only, high value favors two-way effects model over recipient fixed effects. 6 . The Lagrange multiplier (LM) statistic is applied to test the recipient and year effects versus OLS, high value favors random (\&fixed) effects model over OLS. 7. The Hausman statistic is applied to test fixed effects versus random effects, high value favors fixed effects over random effects model.

discussion on one region - the Middle East and North Africa and pay particular attention to the behavior of the USA as a donor. The ranking of fixed effects coefficients for MENA countries are given in Table 3. Donor interest, as represented by the fixed effects coefficient, has a strong positive effect in the allocation of US aid to Israel and Jordan, two of the most strategically important US allies in the region, and a strong negative effect on US aid allocation to Iran, Sudan, and Syria, countries traditionally hostile to US foreign policy in the region.

Next to consider is whether there are changes over time in how aid is allocated, more specifically before and after the Cold War. There was a sea change following the collapse of the Soviet Union. Although time effects included in the 
Table 6. Probit and tobit estimation based on Eqn. (8)

\begin{tabular}{|c|c|c|c|c|c|c|c|}
\hline & Multilateral aid & United States & Canada & France & Italy & Japan & United Kingdom \\
\hline \multicolumn{8}{|l|}{ Probit model } \\
\hline \multirow[t]{2}{*}{$A V E G D P G$} & $0.067^{* * *}$ & $0.039^{* * *}$ & $0.032^{* * *}$ & $0.053^{* * *}$ & $0.040^{* * *}$ & $0.051^{* * *}$ & $0.069^{* * *}$ \\
\hline & $(0.008)$ & $(0.006)$ & $(0.006)$ & $(0.007)$ & $(0.005)$ & $(0.006)$ & $(0.006)$ \\
\hline \multirow[t]{2}{*}{$L G D P P C$} & $-1.156^{* * *}$ & $-1.096^{* * *}$ & $-1.018^{* * *}$ & $-1.109^{* * *}$ & $-0.467^{* * *}$ & $-0.511^{* * *}$ & $-0.639^{* * *}$ \\
\hline & $(0.125)$ & $(0.089)$ & $(0.091)$ & $(0.122)$ & $(0.069)$ & $(0.078)$ & $(0.078)$ \\
\hline \multirow[t]{2}{*}{$L P O P$} & $-0.338^{* * *}$ & 0.113 & $0.213^{* *}$ & 0.076 & $0.570^{* * *}$ & $0.192^{* *}$ & 0.092 \\
\hline & $(0.097)$ & $(0.070)$ & $(0.082)$ & $(0.097)$ & $(0.061)$ & $(0.063)$ & $(0.065)$ \\
\hline Year fixed effects & Included & Included & Included & Included & Included & Included & Included \\
\hline \multirow{2}{*}{$\ln \operatorname{sig} 2 u$} & $0.839^{* * *}$ & $0.733^{* * *}$ & $0.797^{* * *}$ & $0.837^{* * *}$ & $0.665^{* * *}$ & $0.660^{* * *}$ & $0.698^{* * *}$ \\
\hline & $(0.030)$ & $(0.034)$ & $(0.027)$ & $(0.022)$ & $(0.035)$ & $(0.037)$ & $(0.036)$ \\
\hline$N$ & 5,470 & 5,470 & 5,470 & 5,470 & 5,470 & 5,470 & 5,470 \\
\hline \multicolumn{8}{|l|}{ Tobit model } \\
\hline \multirow[t]{2}{*}{$A V E G D P G$} & $0.027^{* * *}$ & $0.029^{* * *}$ & $0.028^{* * *}$ & $0.021^{* * *}$ & $0.031^{* * *}$ & $0.022^{* * *}$ & $0.038^{* * *}$ \\
\hline & $(0.003)$ & $(0.005)$ & $(0.006)$ & $(0.004)$ & $(0.008)$ & $(0.005)$ & $(0.006)$ \\
\hline \multirow[t]{2}{*}{$L G D P P C$} & $-0.785^{* * *}$ & $-1.237^{* * *}$ & $-0.839^{* * *}$ & 0.095 & $-0.993^{* * *}$ & $-0.373^{* * *}$ & $-1.081^{* * *}$ \\
\hline & $(0.046)$ & $(0.076)$ & $(0.088)$ & $(0.072)$ & $(0.132)$ & $(0.066)$ & $(0.088)$ \\
\hline \multirow[t]{2}{*}{$\angle P O P$} & $-0.617^{* * *}$ & $-0.418^{* * *}$ & $-0.337^{* * *}$ & $-0.484^{* * *}$ & $-0.218^{*}$ & $-0.369^{* * *}$ & $-0.487^{* * *}$ \\
\hline & $(0.04)$ & $(0.074)$ & $(0.07)$ & $(0.094)$ & $(0.102)$ & $(0.06)$ & $(0.085)$ \\
\hline Year fixed effects & Included & Included & Included & Included & Included & Included & Included \\
\hline \multirow[t]{2}{*}{ sigma_u } & $0.952^{* * *}$ & $1.867^{* * *}$ & $1.622^{* * *}$ & $2.356^{* * *}$ & $2.248^{* * *}$ & $1.483^{* * *}$ & $2.114^{* * *}$ \\
\hline & $(0.061)$ & $(0.123)$ & $(0.125)$ & $(0.166)$ & $(0.19)$ & $(0.098)$ & $(0.156)$ \\
\hline \multirow[t]{2}{*}{ sigma_e } & $1.073^{* * *}$ & $1.341^{* * *}$ & $1.302^{* * *}$ & $1.051^{* * *}$ & $1.616^{* * *}$ & $1.261^{* * *}$ & $1.347^{* * *}$ \\
\hline & $(0.012)$ & $(0.019)$ & $(0.028)$ & $(0.017)$ & $(0.042)$ & $(0.019)$ & $(0.025)$ \\
\hline$N$ & 5,452 & 5,470 & 5,449 & 5,469 & 5,470 & 5,470 & 5,458 \\
\hline
\end{tabular}

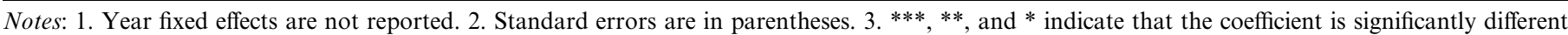
from zero at the $1 \%, 5 \%$, and $10 \%$ levels, respectively.

previous results to some degree account for this, we have not captured changes in the coefficients on the key variables. Strategic considerations are likely to be very different before and after 1989. We therefore introduce a dummy variable (DUM90) which takes value 1 for years from 1990 onwards and interact this variable with all key variables. The results are presented in Table 4.

We find that support by multilateral organization, USA, Canada and Japan to recipients with good policy environment (AVEGDPG) has not changed before and after 1989. It is after 1989 that France has started to respond to recipient's policy environment. For Italy and UK, they still consider recipients' policy environment to be an important factor in their allocation of aid, but its importance has reduced somewhat after 1989. Donors other than France and Japan consistently respond to recipient need (LGDPPC). After 1989 all of these donors except Canada have paid greater attention to recipient need than during the Cold War. Canada has put slightly less emphasis on this factor, but still more than other donors except the USA. It is clearly established earlier, there are different degrees of population bias for different donors. Table 4 demonstrates multilateral organizations, Canada, Japan and the UK have changed their behavior after the Cold War. Multilateral donors and Japan have given greater weight to countries with smaller population while Canada and the UK have started to put more emphasis on countries with larger population since 1989.

As discussed in Section 2, there is often a middle-income bias in aid allocation. We now address this issue as well as the potential "bandwagon effect," which describes the fact that when a recipient receives more aid from one donor, this may attract more from other donors. We replace LGDPPC with GDP per capita (GDPPC) and the square term of GDP per capita $\left(\right.$ GDPPC $^{2}$ ) to capture the middle-income bias effect. We include another variable, aid from other sources (OTHER ODA), to capture the bandwagon effect. The results are reported in Table 5. The coefficients on GDPPC are negative and significant and those on GDPPC ${ }^{2}$ are positive and significant in all the regressions apart from the regression for France. This indicates that these bilateral and multilateral donors display middle-income bias in the process of their aid allocation.

The coefficients on OTHER ODA are statistically significant and positive in all of the regressions for different donors. This lends support to the argument that a "bandwagon effect" exists in the aid allocation process.

So far, our empirical work has only been concerned with the countries that receive a positive amount of aid. However, as Dudley and Montmarquette (1976) have pointed out, in reality the process of aid allocation entails two kinds of question: whether to allocate aid to given potential recipient, and in the case of a positive answer, how much to give to this recipient. Ignoring this (i.e., the truncated nature of the aid variable) may generate bias in the estimation. Responding to this comment, we further run the Probit and Tobit regressions with the random effects using the same set of variables as in Table 1; the results are given in Table 6. The findings for AVEGDPG and LGDPPC are consistent with those in Table 1, indicating that donors tend to respond to good policy environment and recipient need when they decide on whether to allocate aid and how much aid should be allocated to the recipient. However, the coefficient on LPOP exhibits a different pattern across two-way fixed effects, Probit and Tobit models. Tobit models clearly reveal population bias. But donors seem to react differently to the size of recipients when deciding on whether to allocate aid to the recipient.

\section{CONCLUSION}

Our results indicate that both bilateral and multilateral donors respond to recipient need in their allocation of foreign aid. Poorer countries (in terms of GDP per capita) get more 
aid. All donors also respond to a good policy environment in recipients. However, compared to other donors, the United States puts less emphasis on policy environment and recipient need-only about $14.8 \%$ of US aid is allocated on the basis of policy environment and recipient need (and bilateral donors care less about recipient need than multilateral donors). The United States also places more emphasis on its own donor interest (as represented by donor-recipient specific linkages) than others do and in this respect behaves quite differently from other donors. Donor interest seems to be a particularly important aspect in the allocation of US aid to the Middle East and North Africa, Central America, and the Caribbean Basin - all of which have long been regarded by the United States as geopolitically strategic regions. In short, the United States seems to be a more selfish donor than the rest in that it pays less attention to recipient need and more attention to its own interests when allocating its aid budget.

We feel that the above findings are important given the manner in which the United States in the new millennium seems to be articulating a view whereby American interests are increasingly invoked as a justification for aid. An important aspect of these interests is likely to be the pursuit of the War on Terror.
There is already evidence that the allocation of US aid in the Middle East and North Africa, as well as in other strategic regions, has been influenced by linkages between the United States and recipients. Given this finding, there is reason to suspect that such a practice may well intensify in the future.

We also found a "bandwagon effect" in aid allocation, that is, when a recipient receives more aid from one donor this may attract more from other donors as well. In addition, bilateral aid seems to display middle-income bias. Again, both of these findings might have important implications for future aid allocations give the current geopolitical climate. A skewing of US aid toward strategically important countries, such as allies in the MENA region, may have a similar effect on aid from other donors via the bandwagon effect, and given that many such countries are middle-income countries, this may reinforce the middle income bias of bilateral aid allocations. An important question, which deserves research, is whether such potential determinants of future aid allocations will significantly reduce the developmental impact of global aid flows. There is already evidence (Collier \& Dollar, 2002) that sub-optimal geographic aid allocation has reduced the potential poverty alleviation impact of aid.

\section{NOTES}

1. The countries in Mosley et al. (1987) sample are classified into four groups: high aid, high growth; high aid, low growth; low aid, high growth and low aid, low growth. The fact that 22 countries are classified as high aid and low growth (i.e., aid does not seem effective) and 22 are classified as low aid and high growth (i.e., aid does not seem to be necessary) casts doubt on aid effectiveness and also illustrates the country-specific diversity of the aid-growth relationship.

2. Aid tying occurs when donors stipulate that part of the aid funds be used to import goods from the donor country, often at uncompetitive prices.

3. There is ample anecdotal evidence of donor interest influencing aid allocations. Sierra Leone and Israel were both classified as developing countries by the OECD's Development Assistance Committee in 1995 and both had a similar population size. However, Israel is one of the United States's most strategically important allies. From 1969 to 1995, Sierra Leone received an annual average of ODA of US\$74 million, while Israel received US\$937 million which is roughly 13 times the amount allocated to Sierra Leone despite the fact that Israel's income per capita was 27 times that of Sierra Leone.

4. Western aid to Mobuto's Zaire or Marcos's Philippines designed to bolster pro-western anti-communist regimes are good examples.

5. See Mosley et al. (1987) for a discussion of political and commercial pressures for the diffusion of aid allocation; See Hjertholm and White (2000) for the evidence of aid diffusion among countries.

6. It is worth noting here that the population or the middle-income biases may not be free from incentives based either on the recipient's need or on the donor's interest. This is important, since it matters in hypotheses testing and results interpretation. For example, Wittkopf (1972) treats population as an indicator of political importance, unlike others who treat it as an indicator of recipient's need. Maizels and Nissanke (1984) put population in a recipient's need model while dropping it from their donor interest model.

7. The difference between the fixed-effects and random effects is that individual effect is specified as a group specific constant term in the former, while as a group specific disturbance in the later. Unlike the randomeffects model, the error term in the fixed-effects model is assumed to be heteroskedastic and free of autocorrelation. In the case of aid allocation studies, a Tobit model that allows country-specific effects and takes account of the censored nature of the dependent variable may be preferred.

8. In their attempt to assess the robustness and credibility of empirical results obtained in the literature, McGillivray and White (1993) provided a thorough critical assessment of the methodological properties of various statistical models adopted in those studies. Some of their recommendations for improvement of the methodology include using aid commitments instead of aid disbursement as the dependent variable, avoiding separate recipient need and donor interest in models, and giving consideration to the limited dependent variable and non-random sample selection issues.

9. Feeny and McGillivray (2008) develop an aid allocation model in which aid is treated as a private good of a donor country bureaucratic group responsible for bilateral aid allocation. The model is applied to time series data for 10 principal recipients of bilateral official development assistance. Like us, they find that both recipient need and donor interest variables determine the amount of foreign aid to developing countries. They also find that donor allocation behavior often differs markedly among recipients.

10. In this model, a given donor will grant a positive amount of aid to every country.

11. Note, though $\frac{\partial h_{j}}{\partial n_{j}}<0, \frac{\partial H_{j}}{\partial n_{j}}<0$

12. Each individual's welfare change is $-1+\alpha+\gamma<0$. This condition ensures that aid is not a simple cash transfer that substitutes for productive effort.

13. When the total aid to a country is given, holding $p_{j}$ and $\mathrm{y}_{j}$ constant, the marginal impact of population is $1-\alpha-\beta$.

14. Hummels and Levinsoh (1995) use the same approach to capture OECD countries' specific trade relationships. 
15. In other empirical work on aid allocation, the growth rate is interpreted as the absorptive capacity. Although differences exist between the two concepts, it is often the case the better policy environment is, the more efficiently the additional resource can be utilized and therefore the larger the absorptive capacity.

16. According to 2008 DAC Multilateral Aid Report, the overarching aim of multilateral aid is to reduce poverty though each agency may work on a set of functional areas.

17. Only one measure of recipient need, income per capita, is included here. It should be noted another variable capturing recipient need, infant mortality, has also been found to be important in the literature (e.g., Bandyopadhyay \& Wall, 2007, chap. 19; Trumbull \& Wall, 1994).
However, in our sample, the correlation between GDP per capita and infant mortality is -0.70 . This is a clear indication of multicollinearity, as a result, they cannot be introduced into the regressions simultaneously. We, therefore, run regressions with one being included each time. The results are qualitatively similar for common variables LPOP and AVEGDPG. As for Mortality, in OLS without fixed effects models, the variable is positive and statistically significant in all cases except Japan. However, in two-way fixed effects models, only the coefficient in the USA regression is consistent with our expectation and the rest either have the wrong sign or are statistically insignificant. Further analysis reveals that Mortality is highly correlated with country fixed effects. Therefore, in the paper, we focus on GDP per capita only. The results for Mortality are available upon request.

\section{REFERENCES}

Alesina, A., \& Dollar, D. (2002). Who gives foreign aid to whom and why?. Journal of Economic Growth, 5, 33-64.

Arne, B. (2006). Donor coordination and the uses of aid. Working Papers in Economics, 196: Göteborg University.

Arvin, B. M., \& Drewes, T. (2001). Are there biases in German bilateral aid allocation?. Applied Economic Letters, 8, 173-177.

Bandyopadhyay, S., \& Wall, H. J. (2007). The determinants of aid in the post-Cold War era. In H. Beladi, \& E. K. Choi (Eds.), Theory and practice of foreign aid (Frontiers of Economics and Globalization, Volume 1 (pp. 387-402). Emerald Group Publishing Limited.

Barro, R. J., \& Lee, J.-W. (2005). IMF programs: Who is chosen and what are the effects?. Journal of Monetary Economics, 52, 1245-1269.

Berthélemy, J.-C. (2006a). Aid allocation: Comparing donors behaviour. Swedish Economic Policy Review, 13, 75-109.

Berthélemy, J.-C. (2006b). Bilateral donors' interest vs recipients' development motives in aid allocation: Do all donors behave the same? Review of Development Economics, 10, 179-194.

Berthélemy, J.-C., \& Tichit, A. (2004). Bilateral donors' aid allocation decisions - a three-dimensional panel analysis. International Review of Economics \& Finance, 13, 253-274.

Bobba, M., \& Powell, A. (2007). Aid and growth: Politics matters. InterAmerican Development Bank Working Paper No. 601.

Boone, P. (1994). Impact of foreign aid on saving and growth. Centre for Economic Performance. Working Paper 1265.

Bowles, P. (1987). Foreign aid and domestic savings in less developed countries: Some tests for causality. World Development, 15, 789-796.

Burnside, C., \& Dollar, D. (2000). Aid, policies and growth. American Economic Review, 90, 847-869.

Chandrasekhar, S. (1965). American aid and India's economic development. New York: Frederick A. Praeger.

Chong, A., \& Gradstein, M. (2008). What determines foreign aid? The donors' perspective. Journal of Development Economics, 87, 1-13.

Cingranelli, D. L., \& Pasquarello, T. E. (1985). Human rights practices and the US. Distribution of foreign aid to Latin American countries. American Journal of Political Science, 29, 539-563.

Collier, P., \& Dollar, D. (2002). Aid allocation and poverty reduction. European Economic Review, 46, 1475-1500.

Commission on International Development. (1969). Partners in Development. London: Pall Mall Press.

Dalgaard, C.-J., Hansen, H., \& Tarp, F. (2004). On the empirics of foreign aid and growth. Economic Journal, 114, 191-216.

Davenport, M. (1970). The allocation of foreign aid: A cross section study. Yorkshire Bulletin of Economic and Social Research, 22, 26-41.

Dollar, D., \& Levin, V. (2006). The increasing selectivity of foreign aid, 1984-2003. World Development, 34, 2034-2046.

Dowling, J. M., \& Hiemenz, U. (1985). Biases in the allocation of foreign aid. World Development, 3, 535-541.

Dudley, L., \& Montmarquette, C. (1976). A model of the supply of bilateral foreign aid. American Economic Review, 66, 132-142.

Feeny, S., \& McGillivray, M. (2008). What determines bilateral aid allocations? Evidence from time series data. Review of Development Economics, 12, 515-529.

Frank, A. G. (1969). Latin American, underdevelopment or revolution. New York: Monthly Review Press.
Frey, B., \& Schneider, F. (1986). Competing models international lending activity. Journal of Development Economics, 20, 225-245.

Gang, I. N., \& Khan, H. A. (1990). Some determinates of foreign aid to India, 1960-85. World Development, 18, 431-442.

Greene, W. H. (2007). Econometric analysis (6th ed.). New York: Prentice Hall International Inc.

Gulhati, R., \& Nallari, R. (1988). Reform of foreign aid polices: The issue of inter-country allocation in Africa. World Development, 16 , $1167-1184$.

Hansen, H., \& Tarp, F. (2001). Aid and growth regressions. Journal of Development Economics, 64, 547-570.

Harrigan, J., Wang, C., \& El-Said, H. (2006). The economic and political determinants of IMF and World Bank lending in the Middle East and North Africa. World Development, 34, 247-279.

Hayter, T. (1971). Aid as imperialism. New York: Penguin Books.

Hayter, T. (1981). The creation of world poverty: An alternative view to the Brandt report. London: Pluto Press.

Hayter, T., \& Watson, C. (1985). Aid: Rhetoric and reality. London: Pluto Press.

Hensman, C. R. (1971). Rich against poor: The reality of aid. London: Allen Lane.

Hjertholm, P., \& White, H. (2000). Survey of foreign aid: History, trends and allocation. Discussion Papers 00-04, University of Copenhagen. Department of Economics.

Hummels, D., \& Levinsoh, J. (1995). Monopolistic competition and international trade: Reconsidering the evidence. Quarterly Journal of Economics, 799-836.

Isenman, P. (1976). Bias in aid allocations against poorer and larger countries. World Development, 4, 631-641.

Jalée, P. (1968). The pillage of the third world. New York: Monthly Review Press.

Levitt, M. S. (1968). The allocation of economic aid in practice. Manchester School of Economics and Social Studies, 36 , 131-147.

Lewis, H. G. (1986). Union relative wage effects: A survey. Chicago: University of Chicago Press.

Maizels, A., \& Nissanke, M. K. (1984). Motivations for aid to developing countries. World Development, 12, 879-900.

McGillivray, M. (2003). Modelling aid allocation: Issues, approach and results. Journal of Economic Development, 28, 171-188.

McGillivray, M., \& Oczkowski, E. (1991). Modelling the allocation of Australian bilateral aid: A two-part sample selection approach Economic Record, 67, 147-152.

McGillivray, M., \& White, H. (1993). Explanatory studies of aid allocation among developing countries: A critical survey. Hague: Institute of Social Science.

McKinlay, R. D., \& Little, R. (1977). A foreign policy of U S bilateral aid allocation. World Politics, 30, 58-86.

McKinlay, R. D., \& Little, R. (1978). The French aid relationship: A foreign policy model of the distribution of French bilateral aid, 1964 1970. Development and Change, 9, 459-478.

McKinlay, R. D., \& Little, R. (1979). The US aid relationship: The test of recipient need and donor interest models. Political Studies, 27, $235-250$. 
Minoiu, C., \& Reddy, S. G. (2010). Development aid and economic growth: A positive long-run relation. Quarterly Review of Economics and Finance, 50, 27-39.

Mosley, P., Harrigan, J., \& Toye, J. (1995). Aid and power. London and New York: Routledge.

Mosley, P., Hudson, J., \& Horrell, S. (1987). Aid, the public sector and the market in less developed countries. Economic Journal, 97, 616-641.

OECD. (1994). Development co-operation-development assistance committee 1993 report. Paris: Organisation for Economic Co-operation and Development.

Poe, S. C. (1992). Human rights and economic aid under Ronald Reagan and Jimmy Carter. American Journal of Political Science, 36, 147-167.

Poe, S. C., \& Sirirangsi, R. (1993). Human rights and US economic aid to Africa. International Interactions, 18, 309-322.

Riddell, R. (1987). Foreign aid reconsidered. London: James Curry.
Rodrik, D. (1995). Why is there multilateral lending? NBER Working Paper No. w5160.

Thacker, S. C. (1999). The high politics of IMF lending. World Politics, $52,38-75$.

Thiele, R., Nunnenkamp, P., \& Dreher, A. (2007). Do donors target aid in line with the MDGs: A sector perspective of aid allocation. Review of World Economics, 143, 596-630.

Trumbull, W. N., \& Wall, H. J. (1994). Estimating aid-allocation criteria with panel data. The Economic Journal, 104, 876-882.

Wittkopf, E. R. (1972). Western bilateral aid allocations: A comparative study of recipient state attitudes and aid received. Beverly Hills: Sage.

Wittkopf, E. R. (1973). Foreign aid and United Nations votes: A comparative study. American Political Science Review, 67, 868-888.

\section{APPENDIX A. VARIABLE DEFINITIONS AND DATA SOURCES}

\begin{tabular}{|c|c|c|}
\hline & Definitions & Source \\
\hline MULTIMPC & $\begin{array}{l}\text { Total ODA commitment by multilateral organizations divided by population of the } \\
\text { recipient country (constant } 2008 \text { price, US\$) }\end{array}$ & $\begin{array}{l}\text { OECD-DAC } \\
\text { online database }\end{array}$ \\
\hline$D A C M P C$ & $\begin{array}{l}\text { Total ODA commitment by DAC countries divided by population of the recipient } \\
\text { country (constant } 2008 \text { price, US\$) }\end{array}$ & \\
\hline$U S M P C$ & $\begin{array}{l}\text { ODA commitment by United States divided by population of the recipient country } \\
\text { (constant } 2008 \text { price, US\$) }\end{array}$ & \\
\hline$C A N A D A M P C$ & $\begin{array}{l}\text { ODA commitment by Canada divided by population of the recipient country } \\
\text { (constant } 2008 \text { price, US\$) }\end{array}$ & \\
\hline FRANCEMPC & $\begin{array}{l}\text { ODA commitment by France divided by population of the recipient country } \\
\text { (constant } 2008 \text { price, US } \$ \text { ) }\end{array}$ & \\
\hline ITALYMPC & $\begin{array}{l}\text { ODA commitment by Italy divided by population of the recipient country (constant } \\
2008 \text { price, US\$) }\end{array}$ & \\
\hline JAPAPMPC & $\begin{array}{l}\text { ODA commitment by Japan divided by population of the recipient country } \\
\text { (constant } 2008 \text { price, US\$) }\end{array}$ & \\
\hline$U K M P C$ & $\begin{array}{l}\text { ODA commitment by the United Kingdom divided by population of the recipient } \\
\text { country (constant } 2008 \text { price, US\$) }\end{array}$ & \\
\hline$A V E G D P G$ & Three year average GDP growth rate & WDI CD-ROM \\
\hline POP & Population & \\
\hline$G D P P C$ & GDP per capita (constant 1995 Price, US\$) & \\
\hline MORTALITY & Infant mortality rate (per 1,000 live births). Missing values are linearly interpolated & \\
\hline
\end{tabular}

APPENDIX B. DESCRIPTIVE STATISTICS AND CORRELATION MATRIX FOR LISTED VARIABLES

\begin{tabular}{|c|c|c|c|c|c|c|c|c|c|c|c|c|}
\hline Variable & Mean & s.d. & 1. & 3. & 4. & 5. & 6. & 7. & 8. & 9. & 10. & 11. \\
\hline 1. LMULTIMPC & 2.53 & 1.73 & & & & & & & & & & \\
\hline 2. $L U S M P C$ & 1.19 & 2.19 & 0.42 & & & & & & & & & \\
\hline 3. $L C A N A D A M P C$ & -0.73 & 2.05 & 0.47 & 0.38 & & & & & & & & \\
\hline 4. LFRANCEMPC & 0.76 & 2.34 & 0.39 & 0.15 & 0.29 & & & & & & & \\
\hline 5. LITALYMPC & -1.41 & 2.47 & 0.45 & 0.31 & 0.33 & 0.38 & & & & & & \\
\hline 6. LJAPANMPC & 0.36 & 2.18 & 0.28 & 0.25 & 0.13 & 0.06 & 0.10 & & & & & \\
\hline 7. LUKMPC & -0.30 & 2.50 & 0.43 & 0.32 & 0.46 & 0.08 & 0.22 & 0.24 & & & & \\
\hline 8. $\angle P O P$ & 14.85 & 2.17 & -0.49 & -0.40 & -0.40 & -0.46 & -0.41 & -0.26 & -0.51 & & & \\
\hline 9. $L G D P P C$ & 7.10 & 1.37 & -0.25 & 0.00 & -0.04 & 0.04 & -0.04 & 0.00 & -0.03 & -0.38 & & \\
\hline 10. $A V E G D P G$ & 3.89 & 5.23 & -0.05 & -0.02 & -0.04 & 0.02 & -0.08 & 0.01 & 0.04 & 0.02 & 0.12 & \\
\hline 11. MORTALITY & 70.91 & 50.40 & 0.11 & -0.03 & 0.03 & 0.22 & 0.06 & -0.21 & -0.04 & 0.13 & -0.70 & 0.04 \\
\hline
\end{tabular}

Note: The prefix "L" denotes a logged variable. 